\title{
ANALISIS PENGARUH KEMAMPUAN PERUSAHAAN, DAYA RESPON RANTAI PASOK, DAN PRAKTIK MANAJEMEN RANTAI PASOK TERHADAP KEUNGGULAN BERSAING DAN KINERJA PERUSAHAAN (Studi pada Rantai Pasok Pelumas Jawa Tengah)
}

\author{
Rezky Kurniawan¹, Suyudi Mangunwihardjo², Mirwan Surya Perdhana ${ }^{3}$ \\ ${ }^{1}$ Magister Manajemen, Fakultas Ekonomika dan Bisnis, Universitas Diponegoro \\ ${ }^{2}$ Magister Manajemen, Fakultas Ekonomika dan Bisnis, Universitas Diponegoro \\ ${ }_{3}^{3}$ Magister Manajemen, Fakultas Ekonomika dan Bisnis, Universitas Diponegoro
}

\begin{abstract}
ABSTRAK
Penelitian ini dilakukan dengan menganalisis faktor yang mempengaruhi kinerja perusahaan dengan variabel praktik manajemen rantai pasok, daya respon rantai pasok, kemampuan perusahaan dan variabel keunggulan daya saing sebagai variabel intervening. Penelitian ini mengembangkan suatu model teoritis dengan mengajukan lima hipotesis yang akan diuji mengunakan Structural Equation Modelling (SEM) sebagai alat analisis. Responden dari penelitian ini adalah retailer pelumas Pertamina berjumlah 158 retailer yang tersebar di tujuh rayon di area Jawa Tengah dan Yogyakarta. Hasil penelitian ini menunjukkan bahwa kinerja perusahaan dapat ditingkatkan dengan praktik manajemen rantai pasok yang memadai dan keunggulan daya saing perusahaan, serta kemampuan perusahaan berpengaruh positif terhadap keunggulan daya saing perusahaan. Namun daya respon rantai pasok tidak berpengaruh positif dalam meningkatkan kinerja perusahaan.
\end{abstract}

Kata Kunci: praktik manajemen rantai pasok, daya respon rantai pasok, kemampuan perusahaan, keunggulan daya saing, kinerja perusahaan.

\section{PENDAHULUAN}

Di era persaingan bisnis yang semakin ketat, perusahan sangat penting untuk meningkatkan daya saing strategis yang dimiliki. Perusahaan harus dapat memanfaatkan beberapa kemungkinan ceruk untuk menjadi lebih kompetitif dan produktif sehingga dapat meningkatkan kinerja perusahaan (Arawati et al, 2008).

Kinerja perusahaan merupakan tolak ukur indikator sebuah dari perkembangan sebuah perusahaan. Bisnis yang kompetitif adalah fokus kepada bagaimana meningkatkan nilai kepada konsumen yaitu menyediakan produk dan layanan yang lebih bernilai dibandingkan dengan kompetitor (Sukati et al, 2011). Agar suatu perusahaan dapat bersaing dan berkembang, perusahaan harus memiliki daya keunggulan kompetitif. Hal ini mendorong perusahaan untuk dapat bersaing bagaimana menyediakan produk kepada konsumen namun dengan harga yang rendah serta produk dan layanan ke tempat yang tepat dan waktu yang tepat. Banyak perusahaan juga menyadari bahwa 
hal itu tidak cukup untuk meningkatkan efisiensi dalam sebuah organisasi perusahaan, meraka harus membuat seluruh rantai pasokannya lebih kompetitif dan efisien (Li et al, 2006).

Dengan meningkatnya kebutuhan konsumen yang sangat cepat dan adanya beberapa gangguan yang dapat terjadi dalam proses suplai, manajemen rantai pasok sangat diperlukan dalam penyesuaian lingkungan bisnis yang ada. Hal ini secara langsung akan menjadi keunggulan kompetitif bagi perusahaan (Thatte et al, 2013).

Faktor yang tidak kalah pentingnya dalam menciptakan keunggulan daya saing perusahaan adalah kemampuan perusahaan. Tuan et al (2010) dalam penelitian yang berjudul Organisational Capabilities, Competitive Advantage, and Performance In Supporting Industries, menyimpulkan bahwa untuk menciptakan keunggulan daya saing perusahaan dibutuhkan sumber daya individual yang bekerja sama untuk menciptakan kemampuan organisasi yang terintegrasi. Hal yang sama juga diungkapkan oleh HaBrookshire et al (2009), kemampuan organisasi perusahaan berpengaruh positif terhadap keunggulan daya saing perusahaan. Vorhies et al., (2005); HaBrookshire et al., (2009); Tuan et al., (2010) menunjukkan kemampuan perusahaan berpengaruh signifikan positif terhadap keunggulan bersaing, artinya kemampuan perusahaan yang baik mampu meningkatkan keunggulan daya saing perusahaan.

Sukati et al., (2011); Bratic (2011); Thatthe et al., (2013); Li et al., (2014) menunjukkan praktik manajemen rantai pasok berpengaruh signifikan positif terhadap keunggulan bersaing, artinya praktik manajemen rantai pasok yang baik mampu meningkatkan keunggulan bersaing. Sedangkan Singh et al (2010) menunjukkan praktik manajemen rantai pasok berpengaruh signifikan negatif terhadap keunggulan bersaing.

Ueki, (2013) dalam penelitiannya yang berjudul Supply chain collaboration and responsiveness dengan responden 161 Perusahaan sektor industri Elektonik dan Otomotif di Thailand menunjukkan praktik manajemen rantai pasok tidak berpengaruh signifikan terhadap keunggulan bersaing, artinya peningkatan praktik manajemen rantai pasok tidak mempengaruhi keunggulan bersaing.

Berdasarkan penelitian-penelitian yang telah dilakukan tersebut, sebagian besar penelitian berpendapat faktor rantai pasok dan kemampuan perusahaan tidak dapat dipungkiri menjadi hal utama yang berperan dalam meningkatkan kinerja perusahaan, walaupun masih terdapat beberapa peneliti yang memiliki pendapat berbeda dari kesimpulan hasil penelitian yang diperoleh. Sebagian besar penelitian tersebut dilakukan pada responden sektor industri manufaktur.

Salah satu industri yang sangat dipengaruhi oleh faktor rantai pasok adalah industri pelumas. Pelumas merupakan salah satu produk yang tidak kalah pentingnya apabila dibandingkan dengan bahan bakar. Industri pelumas menjadi salah satu industri strategis yang mengalami pertumbuhan cukup pesat, dimana permintaan akan produk pelumas meningkat setiap tahunnya. Kondisi ini didorong dengan semakin meningkatnya jumlah kendaraan bermotor yang banyak memerlukan produk ini serta perkembangan sektor industri yang meliputi produksi dan konstruksi.

Pemilik market share pelumas terbesar saat ini, PT. Pertamina Lubricants melakukan upaya peningkatan kemampuan dalam menaikkan kinerja penjualan dengan 
mengoptimalkan rantai pasok di tingkat retailer, selain menggunakan kekuatan SPBU yang sudah ada saat ini, perusahaan juga mendirikan beberapa outlet resmi dengan fasilitas bengkel yang diberi nama Olimart serta merekrut retailer dengan rebranding beberapa bengkel potensial dengan nama Bengkel Enduro.

Hal yang sama juga dilakukan oleh Shell dengan membentuk Shell Bosch Car Service dan Shell Auto Service, Castrol yang telah membentuk Castrol Bike Point, dan di sisi lain sebagai pabrikan kendaraan bermotor Honda, Yamaha dan Toyota telah memiliki pelumas spesifik untuk kendaraan pabrikannya di bengkel resminya tersebut. Hal ini tentu menambah semakin sengitnya persaingan pasar pelumas di Indonesia. Fenomena yang sejalan dengan tingkat produksi pelumas di Indonesia juga dapat dilihat dari data kinerja pada salah satu distributor merek pelumas kendaraan bermotor pada Grafik 1.

\section{Grafik 1}

\section{Grafik Volume Penjualan Distributor Kendaraan Bermotor}

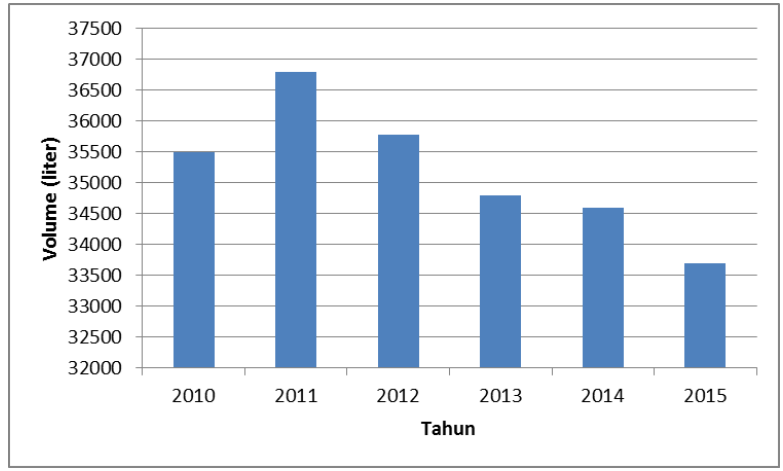

Sumber: Data Distributor Pelumas

Pada Grafik 1 menunjukkan adanya penurunan volume penjualan salah satu merek pelumas pada satu distributornya. Hal ini sangat bertolak belakang dengan pertumbuhan jumlah kendaraan bermotor yang seharusnya berbanding lurus dengan kinerja penjualan pelumas. Adapun penurunan kinerja sebagian besar dihadapi oleh retailer terutama jaringan SPBU, yang selama ini belum optimal. Selain proses rantai pasok yang panjang dengan angka penjualan yang masih relatif kecil, menjadikan SPBU belum berfungsi secara optimal. Pengaruh proses manajemen rantai pasok dan kemampuan SPBU sebagai retailer pelumas dapat menjadi faktor masih rendahnya tingkat kinerja SPBU dari sisi bisnis pelumas. Hal ini berbanding terbalik dengan Enduro dan Olimart yang telah memberikan paket-paket pelayanan ekstra dalam proses meningkatkan kinerja penjualan pelumas Pertamina. Hubungan antara bengkel dan pelanggan pun jauh lebih baik bila dibandingkan dengan pelayanan penjualan yang diterima di SPBU, sehingga hal ini dapat menjadi faktor yang sangat menentukan terkait masih rendahnya tingkat kinerja SPBU sebagai titik penjualan pelumas kepada end customer.

Permasalahan dalam penelitian didukung adanya fenomena gap yaitu adanya penurunan omzet penjualan distributor salah satu merek pelumas 
sebesar 3\% per tahun, masalah tersebut muncul akibat adanya persaingan yang semakin ketat dan potensi permintaan yang akan hilang dengan ditandai dengan adanya penurunan omzet atau angka penjualan, namun kondisi pasar yang sebenarnya masih dapat dikembangkan seiring dengan meningkatnya angka pertumbuhan kendaraan bermotor maupun pengguna di lingkungan industri.

Permasalahan dalam penelitian ini juga didukung adanya perbedaan hasil penelitian terdahulu (research gap), yang menguji pengaruh praktik manajemen rantai pasok terhadap kinerja perusahaan, dimana Hasan (2012); Paulraj et al., (2012); Hsu et al., (2009); Tan (2002); dan Li et al., (2006) menunjukkan adanya pengaruh positif sedangkan Singh et al (2010) menunjukkan pengaruh negatif serta menguji pengaruh kemampuan perusahaan dan daya respon rantai pasok dalam meningkatkan daya saing perusahaan dimana Vorhies et al., (2005); HaBrookshire et al., (2009); Tuan et al., (2010) menunjukkan adanya pengaruh positif sedangkan Yeoh et al, (1999) menunjukkan hubungan yang tidak signifikan.

Berdasarkan fenomena gap dan research gap diatas, dapat dijabarkan dalam bentuk pertanyaan penelitian sebagai berikut:

1. Apakah kemampuan perusahaan berpengaruh terhadap keunggulan bersaing?

2. Apakah praktik manajemen rantai pasok berpengaruh terhadap keunggulan bersaing?

3. Apakah daya respon rantai pasok berpengaruh terhadap keunggulan bersaing?

4. Apakah keunggulan bersaing berpengaruh terhadap kinerja perusahaan?
5. Apakah praktik manajemen rantai pasok berpengaruh terhadap kinerja perusahaan?

\section{TELAAH PUSTAKA}

\section{Resource Based View Theory}

Resource Based View (pandangan berbasis pada sumber daya perusahaan) adalah pandangan dari internal perusahaan berdasarkan teori yang dirancang untuk menjelaskan perbedaan dalam perilaku perusahaan dan kinerja (Barney ,1991). Pada teori ini, perusahaan dibutuhkan untuk memiliki sumber daya yang berbeda dan cara dimana perusahaan dapat melakukan akuisisi, pengembangan, memelihara dan menerapkan sumber daya untuk mengarah pada keunggulan kompetitif dan kinerja yang unggul dari waktu ke waktu (Teece et al, 1997).

Resource Based View menjelaskan bahwa sumber daya dan kemampuan perusahaan harus berharga, langka, sulit untuk ditiru dan perusahaan memiliki sumber daya komplementer untuk meningkatkan dan memaksimalkan kemampuan. Hal ini sangat berguna dalam mendorong keunggulan kompetitif yang berkelanjutan. (Barney, 1991). Dalam perspektif penyediaan sumber daya, teori Resource Based View secara tradisional menyatakan bahwa perusahaan tidak boleh melakukan outsourcing pada fungsi bisnisnya atau kegiatan yang memberikan kontribusi untuk membangun dan memelihara keunggulan kompetitif perusahaan. Perusahaan yang menjalin hubungan dengan perusahaan eksternal memiliki risiko dalam melakukan transfer pengetahuan dan sumber daya vital yang terlibat dalam kerjasama kemitraannya (Barney, 1991). 


\section{Kinerja Perusahaan}

Kinerja Perusahaan mencerminkan seberapa baik perusahaan dalam mencapai tujuan pasarnya maupun tujuan dari sisi finansial. Tujuan jangka pendek dari manajemen rantai pasok adalah meningkatkan produktivitas, mengurangi inventori dan siklus produksi, sedangkan tujuan jangka panjangnya adalah meningkatkan pangsa pasar dan profit untuk keseluruhan partner yang terlibat dalam rantai pasok organisasi ( $\mathrm{Li}$ et al, 2006).

Barney (1991) dalam penelitiannya yang berjudul "Firm resources and sustained competitive advantage" berpendapat bahwa asset, kapabilitas, proses organisasi, atribut perusahaan yang dimiliki dan dikendalikan oleh perusahaan memiliki peran dalam peningkatan efektifitas dan efisiensi perusahaan dalam mencapai kinerja perusahaan yang superior. Dalam penelitian Rose et al (2010), performa perusahaan dapat digambarkan menjadi dua dimensi yaitu dimensi finansial dan non finasial, yang mana elemen utamanya digambarkan berdasarkan penjualan (sales-based) dan organisasi (organizational-based).

Kinerja Perusahaan merupakan tolak ukur yang penting bagi suatu perusahaan dan dapat mencerminkan suatu perusahaan telah mencapai keunggulan bersaing atau tidak. Pendekatan dalam pengukuran Kinerja Perusahaan digunakan indikator kinerja operasional dan kinerja ekonomi (Carvalho et al, 2012).Penelitian ini mengembangkan pengukuran kinerja perusahaan merujuk pada beberapa penelitian terdahulu.Adapun Indikator yang akan digunakan untuk menggambarkan variabel kinerja perusahaan yaitu: kinerja keuangan, kinerja pemasaran, kinerja operasional, kinerja penyediaan, hubungan pelanggan dan biaya operasional.

\section{Keunggulan Daya Saing}

Keunggulan Daya Saing dapat diartikan sebagai kemampuan organisasi untuk menciptakan sebuah posisi pertahanan diatas semua pesaingnya ( $\mathrm{Li}$ et al, 2006). Pendekatan dalam keunggulan daya saing berpusat pada kemampuan perusahaan untuk menjadi low cost producer dalam industrinya atau menjadi unik dalam industrinya yang akan memberikan nilai tersendiri bagi pelanggan (Porter, 1985). Proses pengenalan produk dengan harga yang rendah atau kualitas yang lebih tinggi sangat menarik perhatian pelanggan. Untuk itu dibutuhkan suatu keunikan produk atau jasa yang akan diberikan. Hal ini yang menjadi penyebab mengapa terdapat sebagian pelanggan yang memiliki brand loyalti tinggi akan suatu produk atau jasa.

Semakin ketatnya iklim persaingan, setiap perusahaan akan berusaha untuk mencari posisi untuk bertahan dengan menggunakan keunggulan daya saing. Porter (1985) mendefinisikan dua tipe keunggulan daya saing perusahaan yang dapat dilakukan diatas pesaing yaitu lower cost dan differentiation. Dua jenis keunggulan daya saing ini dapat membawa perusahaan untuk unggul dalam pasar. Penelitian ini mengembangkan pengukuran keunggulan daya saing merujuk pada beberapa penelitian terdahulu.Adapun Indikator yang akan digunakan untuk menggambarkan variabelkeunggulan daya saing yaitu harga, kualitas, ketergantungan penyediaan, time to market, strategi rantai pasok dan inovasi produk/jasa.

\section{Praktik Manajemen Rantai Pasok}

Manajemen rantai pasok adalah suatu jaringan mulai dari memproduksibahan baku, mengubah mereka menjadi barang setengah jadi dan kemudian produk akhir, serta memberikan produk kepada 
pelanggan melalui sistem distribusi.Tujuan dasar dari manajemen rantai pasok adalah untuk "mengoptimalkan kinerja rantai untuk menambah nilai sebanyak mungkin dengan biaya seminimal mungkin". Dengan kata lain, hal ini bertujuan untuk menghubungkan semua agen rantai pasokan untuk bersama-sama bekerja sama dalam perusahaan untuk memaksimalkan produktivitas dalam rantai pasokan dan memberikan manfaat untuk semua pihak terkait (Finch, 2006). Alasan dan tujuan utama adanya manajemen rantai pasok adalah untuk menyediakan sebuah senjata yang strategis dalam membangun keunggulan kompetitif yang berkelanjutan dengan pengurangan biaya tanpa mengurangi tingkat kepuasan pelanggan (Mentzer et al, 2001).

$\mathrm{Li}$ et al. (2006) menjelaskan bahwa strategic supplier partnership, customer relationship dan information sharing adalah kunci dari manajemen rantai pasok. Penelitian ini mengembangkan pengukuran praktik manajemen rantai pasok merujuk pada beberapa penelitian terdahulu.Adapun Indikator yang akan digunakan untuk menggambarkan variabel praktik manajemen rantai pasok yaitu hubungan stratejik dengan supplier, hubungan pelanggan, pertukaran informasi, praktik penundaan, penggunaan teknologi dan kualitas pertukaran informasi.

\section{Daya Respon Rantai Pasok}

Daya respon rantai pasok diartikan sebagai kemampuan dalam kecepatan dimana rantai pasok dapat mengantisipasi perubahan dalam permintaan konsumen (Holweg, 2005). Tingkat daya respon adalah gabungan antara daya respon operasional (operation responsiveness), daya respon proses logistik (logistic process responsiveness) dan daya respon jaringan supplier (supplier network responsiveness) (Thatte et al, 2013). Dalam dunia kompetetif yang cepat sekali berubah, kebutuhan akan rantai pasok yang fleksibel dan responsif sangat diperlukan.

Dalam penelitiannya Prater et al. (2001) menjelaskan bahwa dengan tingkat kecepatan dan fleksibilitas yang tinggi dalam rantai pasok maka tingkat responsif rantai pasok tersbut semakin meningkat. Berdasarkan beberapa penelitian (Prater et al, 2001), dapat diidentifikasi bahwa terdapat tiga dimensi dalam supply chain responsiveness antara lain: daya respon operasional (operation responsiveness), daya respon proses logistik (logistic process responsiveness) dan daya respon jaringan supplier (supplier network responsiveness).

Penelitian ini mengembangkan pengukuran daya respon rantai pasok merujuk pada beberapa penelitian terdahulu. Adapun Indikator yang akan digunakan untuk menggambarkan variabel daya respon rantai pasok yaitu daya respon sistem operasi, daya respon proses logistik, daya respon jaringan supplier, pertukaran informasi, kompetensi manajemen, dan fleksibilitas suplai.

\section{Kemampuan Perusahaan}

Kemampuan Perusahaan (Firm Capabilities) adalah suatu set kumpulan dari keterampilan dan akumulasi pengetahuan yang diproses dalam suatu organisasi. Kemampuan perusahaan memungkinkan perusahaan untuk mengoptimalkan proses koordinasi setiap kegiatan dan pemanfaatan aset. (Day et al, 1994). Kemampuan perusahaan berbeda dengan aset perusahaan. Kemampuan perusahaan tidak dapat dinilai menggunakan nilai moneter. Kemampuan perusahaan tertanam dalam setiap rutinitas kegiatan perusahaan dan tidak dapat dengan mudah ditiru atau diperdagangkan 
seperti sumber daya fisik aset. Dalam mengeksplorasi kinerja perusahaan dapat diungkapkan bahwa kemampuan dalam interpretasi pasar, relasi dan layanan merupakan kemampuan utama yang dapat mempengaruhi keunggulan kompetitif perusahaan (Ha-Brookshire et al, 2009).

Kemampuan perusahaan mengacu pada kemampuan dalam melakukan serangkaian tugas yang terkoordinasi, memanfaatkan sumber daya organisasi dengan tujuan untuk mencapai suatu hasil tertentu (Helfat et al, 2003). Penelitian ini mengembangkan pengukuran kemampuan perusahaan merujuk pada beberapa penelitian terdahulu. Adapun Indikator yang akan digunakan untuk menggambarkan variabel kemampuan perusahaan yaitu kemampuan menekan biaya, kemampuan pelayanan, kemampuan menginterpretasi pasar, kemampuan manajemen relasi, kemampuan integrasi, dan kemampuan teknologi.

\section{Pengaruh Kemampuan Perusahaan terhadap Keunggulan Daya Saing}

Pentingnya kemampuan perusahaan secara strategis terlaetak pada kontribusinya dalam menciptakan keunggulan daya saing dan profitabilitas yang superior (Day et al, 1994). Keunggulan kompetitif perusahaan harus konsisten dengan nilai relatif yang dihasilkan oleh sumber daya relatif perusahaan dalam memproduksi nilai tersebut (Barney, 1991).

Semakin tinggi kemampuan perusahaan maka akan semakin meningkatkan keunggulan daya saing perusahaan (Tuan et al ,2010; Ha-brookshire et al ,2009). Terdapat tiga sumber yang akan membentuk keunggulan daya saing yaitu kemampuan keuangan, kemampuan strategis dan kemampuan teknologi (Ulrich, 1991). Dengan adanya kemampuan perusahaan yang tinggi maka akan berpengaruh positif dalam menciptakan keunggulan perusahaan. Berdasarkan beberapa hasil penelitian tersebut maka peneliti mengambil sebuah hipotesis:

H1: Kemampuan perusahaan berpengaruh positif terhadap keunggulan daya saing perusahaan

\section{Pengaruh Praktik Manajemen Rantai Pasok terhadap Keunggulan Daya Saing}

Praktik manajemen rantai pasok memiliki hubungan dalam menciptakan daya keunggulan kompetitif perusahaan (Sukati et al 2011). Praktik manajemen rantai pasok secara empirik memiliki pengaruh positif terhadap keunggulan daya saing (Li et al, 2006 ; Mzoughi et al 2008). Hubungan stratejik dengan suplier, kedekatan hubungan antara perusahaan dan pemasok dapat mempengaruhi daya keunggulan kompetitif perusahaan (Ashsish et al, 2013). Semakin dekat hubungan antara perusahan dan pemasok dan pertukaran informasi berjalan dengan lancar maka akan meningkatkan daya saing perusahaan.

Pada penelitian Metilda et al (2011) yang berjudul Impact of Supply Chain Management practices on the competitive advantage of Indian retail supermarkets, mengidentifikasi Supply Chain Management Practice berpengaruh positif signifikan terhadap Competitive Advantage. Berdasarkan beberapa hasil penelitian tersebut maka peneliti mengambil sebuah hipotesis:

H2: Praktik manajemen rantai pasok berpengaruh positif terhadap keunggulan daya saing

\section{Pengaruh Daya Respon Rantai Pasok terhadap Keunggulan Daya Saing}

Daya responsif perusahaan pada praktik rantai pasoknya, daya respon rantai pasok memiliki pengaruh positif pada 
pembentukan keunggulan daya saing perusahaan (Sukati et al, 2011). Pada studinya, Sukati et al (2011) menemukan adanya pengaruh positif antara indikator operational system responsiveness, logistic process responsiveness dan supplier network responsiveness memiliki hubungan positif terhadap keunggulan daya saing. Dengan menjalankan operasional yang responsif, perusahaan akan mampu bersaing dengan keunggulan pada biaya, waktu masuk ke pasar, dan ketergantungan pasokan dari konsumen. Proses logistik yang responsif juga dapat menjadi keunggulan perusahaan (Thatte et al, 2013).

dapat merespon perubahaan untuk permintaan pelanggan dapat meningkatkan keunggulan daya saing perusahaan dari segi penyediaan produk. Semakin tinggi tingkat daya respon rantai pasok sebuah perusahaan akam berpengaruh positif signifikan terhadap keunggulan daya saing perusahaan tersebut (Al-Hawajreh et al ,2014 ; Lummus et al, 2003). Berdasarkan beberapa hasil penelitian tersebut maka peneliti mengambil sebuah hipotesis :

H3: Daya respon rantai pasok berpengaruh positif terhadap keunggulan daya saing

\section{Pengaruh Keunggulan Daya Saing terhadap Kinerja Perusahaan}

Keunggulan daya saing suatu perusahaan menggambarkan bahwa sebuah perusahaan memiliki satu atau lebih keungugulan dibandingkan dengan pesaing lainnya. Keunggulan daya saing dapat membawa perusahaan untuk mencapai level kinerja ekonomis yang lebih tinggi, kepuasan dan loyalitas pelanggan dan hubungan pelanggan yang efektif. Merek perusahaan dengan loyalitas pelanggan yang tinggi akan cenderung dapat menghindari adanya kompetisi dalam perpindahan merek sesuai dengan segmen pasar yang ditarget yang mana secara langsung dapat meningkatkan penjualan dan profitabilitas (Li et al 2006).

Suatu perusahaan yang menawarkan produk berkualitas tinggi dapat ditawarkan dengan harga yang tinggi dan sekaligus meningkatkan profit margin perusahaan dan return on investment ( $\mathrm{Li}$ et al 2006). Keunggulan daya saing berpengaruh positif signifikan terhadap kinerja perusahaan (Mentzer et al, 2000, Mzoughi et al, 2014). Berdasarkan penelitian tersebut, maka dapat dilihat adanya hubungan positif antara keunggulan daya saing dengan kinerja perusahaan. Maka peneliti dapat menyusun hipotesis sebagai berikut:

H4: Keunggulan daya saing berpengaruh positif terhadap kinerja perusahaan

\section{Pengaruh Praktik Manajemen Rantai Pasok terhadap Kinerja Perusahaan}

Li et al (2006) dalam penelitiannya yang berjudul The impact of supply chain management practices on competitive advantage and organizational performance, memperoleh kesimpulan bahwa praktik manajemen rantai pasok memiliki pengaruh positif signifikan terhadap peningkatan kinerja perusahaan.

Dengan memperkuat strategic supplier partnership dalam praktik manajemen rantai pasok dapat meningkatkan kinerja organisasi. Organisasi seharusnya memberikan perhatian yang besar pada peningkatan yang berkelanjutan terkait strategic supplier partnership dalam proses manajemen rantai pasoknya agar dapat memberikan pengaruh positif terhadap kinerja organisasi. (Arawati et al, 2008).

Praktik manajemen rantai pasok memberikan keuntungan perusahaan dari sisi kemampuan manufaktur yang dimiliki dengan mempengaruhi keahlian dan 
kerjasama partner kunci rantai pasoknya. Berdasarkan beberapa hasil penelitian tersebut maka peneliti mengambil sebuah hipotesis :
H5: Praktik manajemen rantai pasok berpengaruh positif terhadap kinerja perusahaan

\section{Gambar 1}

Kerangka Penelitian

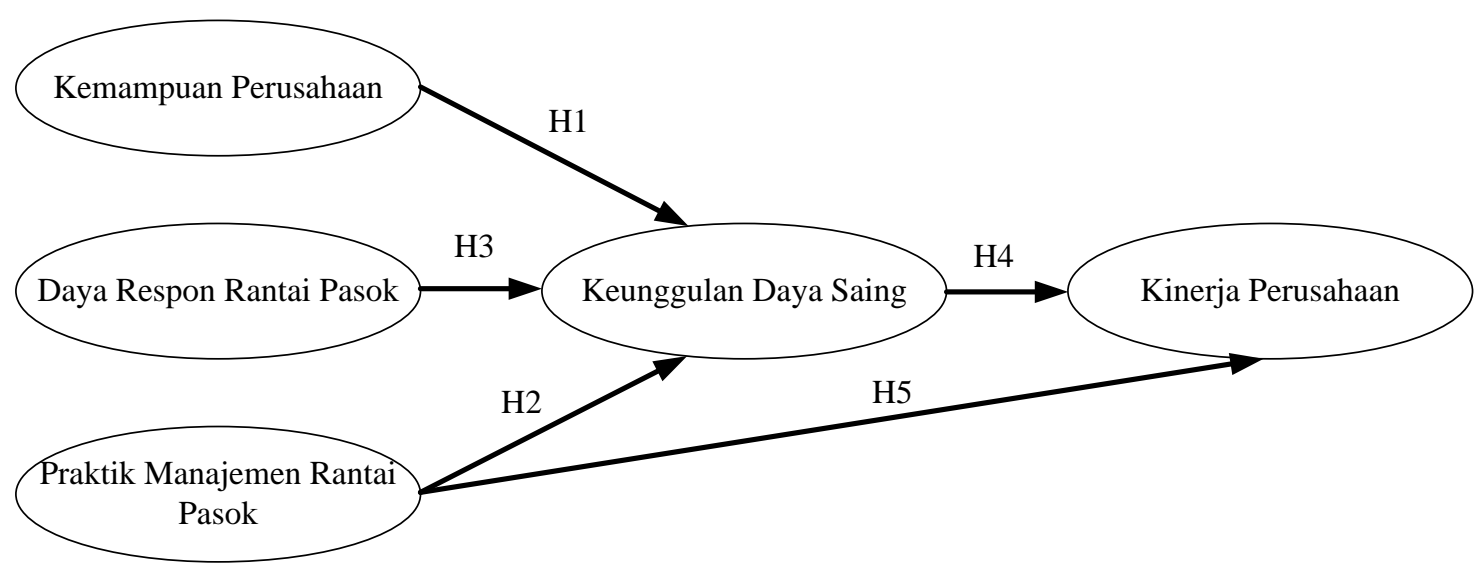

Sumber: Adaptasi dari penelitian Tuan et al (2010); Li et al (2006); Thatte A et al (2013); Singh et al (2010); Arawati et al (2008); dikembangkan untuk penelitian ini, (2018).

\section{METODE PENELITIAN}

Obyek dalam penelitian ini adalah Distributor pada level retailer Pelumas Pertamina di area distribusi Jawa Tengah dengan jumlah 158 responden yang terbagi dalam 7 area rayon. Teknik analisis yang digunakan adalah analisis menggunakan Structural Equation Modelling dengan analisis konfirmatori faktor, uji hipotesis menggunakan teknik estimasi Maximum Likehood Estimation (MLE) denganlevel of significance $5 \%$ serta menggunakan Goodness Fit of Index untuk pengujian kelayakan model yang dikembangkan.

\section{IV.HASIL DAN PEMBAHASAN \\ Analisis Faktor Konfirmatori Konstruk Eksogen}

Pada proses analisis faktor konfirmasi ini diperoleh hasil pengukuran terhadap indikator-indikator yang membentuk variabel laten dalam model penelitian. Variabel-variabel laten atau konstruk eksogen terdiri dari 3 variabel laten dengan 18 indikator. Hasil pengolahan data pada analisis konfirmatori konstruk eksogen adalah pada Gambar 2. Pada Gambar 2 (kiri), hasil pengolahan data menggunakan AMOS menunjukkan beberapa indikator memiliki nilai loading factor dibawah 0,7 sehingga indikator tersebut dapat dipertimbangkan untuk dieliminasi. Pada Gambar 2 (kanan) adalah hasil setelah 
proses eliminasi beberapa indikator yang lemah. dapat dianggap memiliki pengaruh yang

\section{Gambar 2}

Analisis Konfirmatori Faktor Konstruk Eksogen

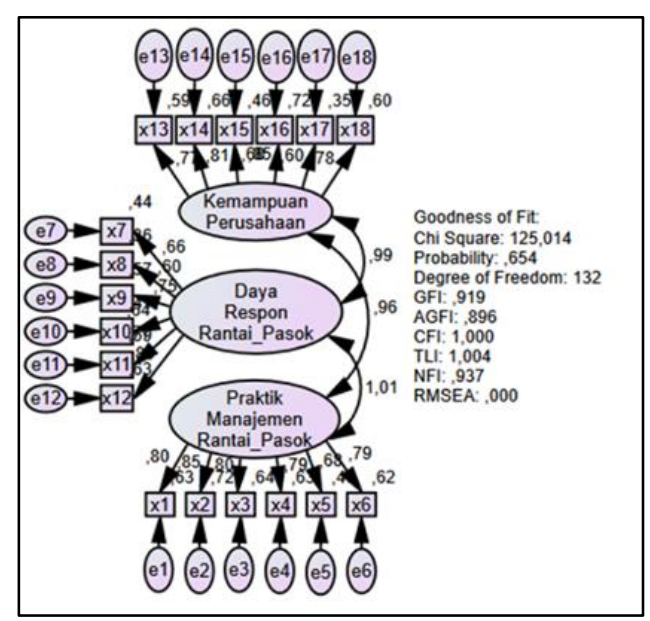

Analisis Faktor Konfirmatori Konstruk Endogen

Variabel-variabel laten atau konstruk endogen pada analisis faktor konfirmatori Konstruk Endogen terdiri dari 2 variabel laten dengan 12 indikator. Hasil pengolahan data pada analisis konfirmatori konstruk endogen adalah pada Gambar 3. Pada gambar 3 (kiri), hasil pengolahan data

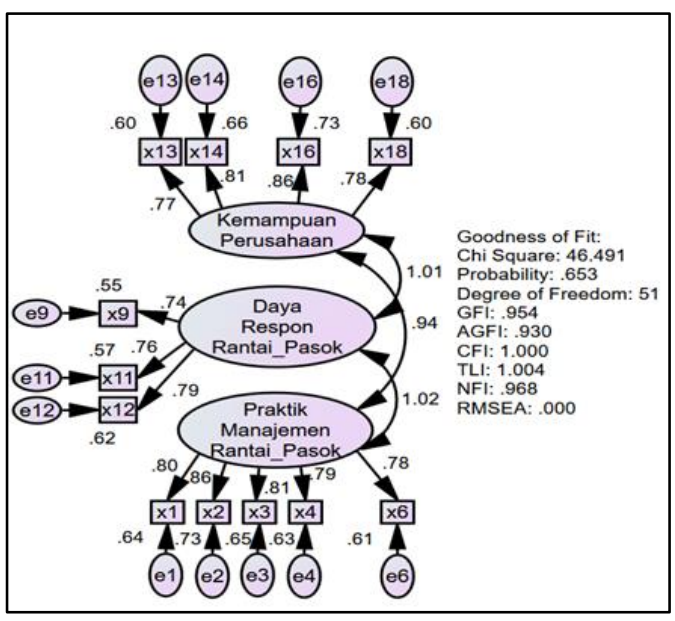

menggunakan AMOS menunjukkan beberapa indikator memiliki nilai loading factor dibawah 0,7 sehingga indikator tersebut dapat dipertimbangkan untuk dieliminasi. Pada gambar 3 (kanan) adalah hasil setelah proses eliminasi beberapa indikator yang dapat dianggap memiliki pengaruh yang lemah.

\section{Gambar 3}

\section{Analisis Faktor Konfirmatori Konstruk Endogen}

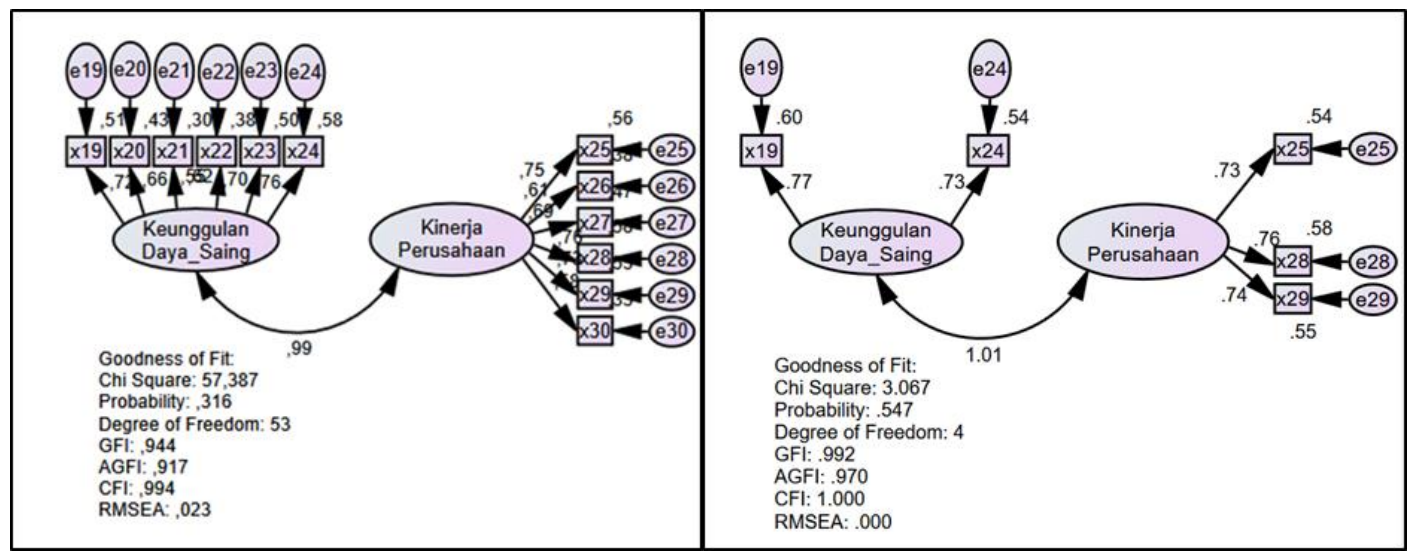

\section{Analisis Faktor Konfirmatori Full Model} Setelah dilakukan proses eliminasi untuk masing-masing konstruk, maka proses selanjutnya adalah pengujian model secara keseluruhan. Adapun hasil uji model secara keseluruhan dapat dilihat pada Gambar 4. 
Berdasarkan pada hasil pengolahan dan analisis terhadap keseluruhan model, menunjukkan bahwa indikator setelah modifikasi yang digunakan dalam membentuk model penelitian telah memenuhi kriteria-kriteria dalam goodness of fit. Dengan demikian variabel-variabel yang digunakan pada model penelitian telah memenuhi kriteria kelayakan.

\section{Gambar 4}

Analisis Konfirmatori Faktor Full Model

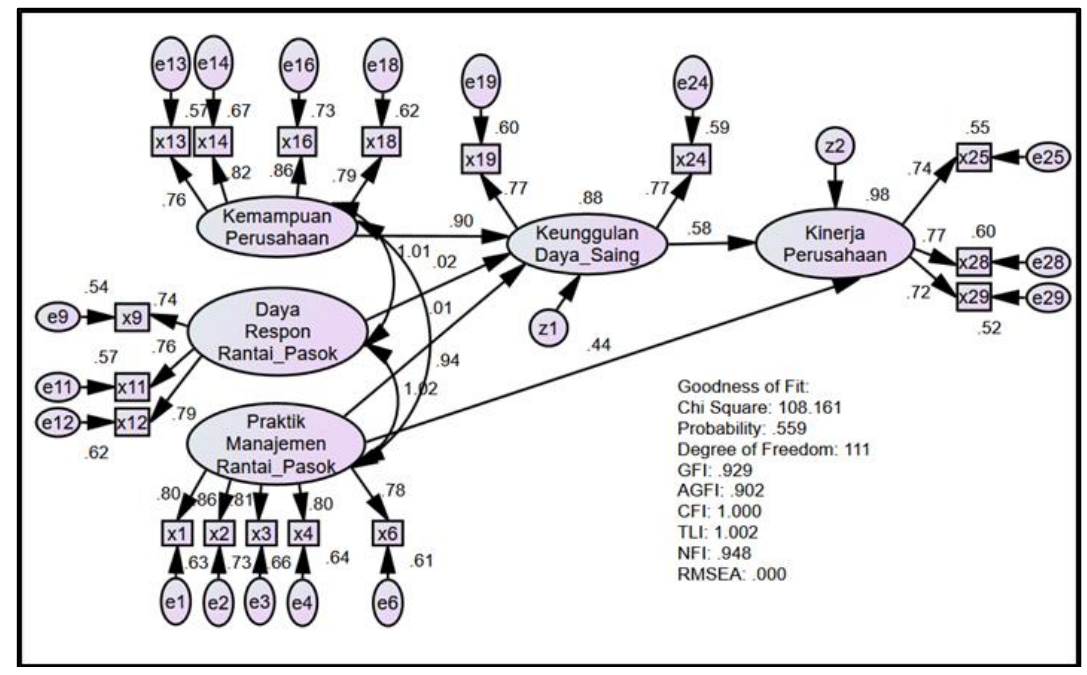

Tabel 1

Hasil Analisis Total Effect

\begin{tabular}{|l|rrrrr|}
\hline & $\begin{array}{r}\text { Kemampuan } \\
\text { _Perusahaan }\end{array}$ & $\begin{array}{r}\text { Daya_Respon_ } \\
\text { Rantai_Pasok }\end{array}$ & $\begin{array}{r}\text { Praktik_Manajemen } \\
\text { _Rantai_Pasok }\end{array}$ & $\begin{array}{r}\text { Keunggulan__ } \\
\text { Daya_Saing }\end{array}$ & $\begin{array}{r}\text { Kinerja_Per } \\
\text { usahaan }\end{array}$ \\
\hline $\begin{array}{l}\text { Keunggulan_ } \\
\text { Daya_Saing }\end{array}$ & .904 & .020 & .014 & .000 & .000 \\
$\begin{array}{l}\text { Kinerja_Peru } \\
\text { sahaan }\end{array}$ & .522 & .012 & .450 & .577 & .000 \\
\hline
\end{tabular}

Berdasarkan Tabel 1, dapat dilihat bahwa terdapat efek total dari kemampuan perusahaan terhadap keunggulan daya saing sebesar 0,904 dan terhadap kinerja perusahaan sebesar 0,522. Efek total dari daya respon rantai pasok terhadap keunggulan daya saing sebesar 0,020 dan terhadap kinerja perusahaan sebesar 0,012. Efek total dari praktik manajemen rantai pasok terhadap keunggulan daya saing sebesar 0,014 dan terhadap kinerja perusahaan sebesar 0,450. Sedangkan efek total dari keunggulan daya saing terhadap kinerja perusahaan sebesar 0,577. Sedangkan untuk hasil uji regresi pada full model dapat dilihat pada Tabel 2. Pada tabel tersebut dapat dilihat hasil uji untuk masing-masing hipotesis. 
Tabel 2

Hasil Uji Regression Weights pada Full Model

\begin{tabular}{|c|c|c|c|c|c|}
\hline & & Estimate & S.E. & C.R. & $\mathbf{P}$ \\
\hline Keunggulan_Daya_Saing & <-- Kemampuan_Perusahaan & .872 & .327 & 2.665 & .008 \\
\hline Keunggulan_Daya_Saing & <-- Praktik_Manajemen_Rantai_Pasok & .014 & .409 & .033 & .973 \\
\hline Keunggulan_Daya_Saing & <-- Daya_Respon_Rantai_Pasok & .019 & .420 & .045 & .964 \\
\hline Kinerja_Perusahaan & <-- Keunggulan_Daya_Saing & .490 & .160 & 3.063 & .002 \\
\hline Kinerja_Perusahaan & <-- Praktik_Manajemen_Rantai_Pasok & .365 & .149 & 2.443 & .015 \\
\hline
\end{tabular}

\section{Pembahasan}

\section{Pengaruh Kemampuan Perusahaan terhadap Keunggulan Daya Saing}

Pengujian hipotesis 1 menunjukkan hasil perhitungan yang diperoleh dari CR sebesar 2,665 dengan probabilitas sebesar 0,008 yang lebih kecil dari 0,05, hal ini menandakan bahwa kemampuan perusahaan mempunyai pengaruh positif tehadap keunggulan daya saing, dengan demikian maka $\mathrm{H} 1$ diterima. Hasil dari penelitian ini menunjukkan kemampuan perusahaan yang memadai akan meningkatkan keunggulan daya saing.

\section{Pengaruh Praktik Manajemen Rantai Pasok terhadap Keunggulan Daya Saing}

Pengujian hipotesis 2 menunjukkan hasil perhitungan yang diperoleh dari CR sebesar 0,033 dengan probabilitas sebesar 0,973 yang lebih besar dari 0,05, hal ini menandakan bahwa praktik manajemen rantai pasok tidak mempunyai pengaruh positif tehadap keunggulan daya saing, dengan demikian maka $\mathrm{H} 2$ ditolak. Hasil dari penelitian ini menunjukkan praktik manajemen rantai pasok yang memadai tidak akan meningkatkan keunggulan daya saing. Manajemen yang mumpuni dalam proses rantai pasok juga telah menjadi hal yang wajib bagi pelaku industri pelumas, sehingga hal ini yang menyebabkan praktik manajemen rantai pasok tidak dapat menjadi keunggulan daya saing yang membedakan antar distributor pelumas.

\section{Pengaruh Daya Respon Rantai Pasok terhadap Keunggulan Daya Saing}

Pengujian hipotesis 3 menunjukkan hasil perhitungan yang diperoleh dari CR sebesar 0,045 dengan probabilitas sebesar 0,964 yang lebih besar dari 0,05, hal ini menandakan bahwa daya respon rantai pasok tidak mempunyai pengaruh positif tehadap keunggulan daya saing, dengan demikian maka H3 ditolak. Hasil dari penelitian ini menunjukkan daya respon rantai pasok yang memadai tidak akan meningkatkan keunggulan daya saing. Hal yang sama juga dialami oleh variabel daya respon rantai pasok, kecepatan dalam rantai pasokan juga telah menjadi hal yang wajib bagi pelaku industri pelumas, sehingga hal ini yang menyebabkan daya respon rantai pasok tidak dapat menjadi keunggulan daya saing yang membedakan antar distributor pelumas. 
Pengaruh Keunggulan Daya Saing terhadap Kinerja Perusahaan

Pengujian hipotesis 4 menunjukkan hasil perhitungan yang diperoleh dari CR sebesar 3,063 dengan probabilitas sebesar 0,002 yang lebih kecil dari 0,05 , hal ini menandakan bahwa keunggulan daya saing mempunyai pengaruh positif tehadap kinerja perusahaan, dengan demikian maka H4 diterima. Hasil dari penelitian ini menunjukkan keunggulan daya saing yang memadai akan meningkatkan kinerja perusahaan.

\section{Pengaruh Praktik Manajemen Rantai Pasok terhadap Kinerja Perusahaan}

Pengujian hipotesis 5 menunjukkan hasil perhitungan yang diperoleh dari CR sebesar 2,443 dengan probabilitas sebesar 0,015 yang lebih kecil dari 0,05, hal ini menandakan bahwa praktik maajemen rantai pasok mempunyai pengaruh positif tehadap kinerja perusahaan, dengan demikian maka H5 diterima. Hasil dari penelitian ini menunjukkan praktik manajemen rantai pasok yang optimal akan meningkatkan kinerja perusahaan.

\section{KESIMPULAN DAN SARAN Kesimpulan}

Penggunaan data penelitian ini terdistribusi secara normal dan tidak terjadi multikolinearitas. Kesimpulan dari lima hipotesis adalah sebagai berikut:

1. Kemampuan perusahaan berpengaruh positif terhadap keunggulan daya saing. Kemampuan perusahaan yang memadai akan memberikan dampak pada keunggulan daya saing perusahaan yang lebih baik.

2. Praktik manajemen rantai pasok tidak memiliki pengaruh terhadap keunggulan daya saing. Praktik manajemen rantai pasok yang baik belum tentu dapat memberikan kontribusi pada keunggulan daya saing.

3. Daya respon rantai pasok tidak memiliki pengaruh terhadap keunggulan daya saing. Daya respon rantai pasok yang baik belum tentu dapat memberikan kontribusi pada keunggulan daya saing.

4. Keunggulan daya saing berpengaruh positif terhadap kinerja perusahaan. Semakin tinggi keunggulan daya saing perusahaan maka akan meningkatkan kinerja perusahaan yang lebih baik.

5. Praktik manajemen rantai pasok berpengaruh positif terhadap kinerja perusahaan. Semakin memadai proses manajemen rantai pasok yang dijalankan maka akan meningkatkan kinerja perusahaan yang lebih baik.

\section{Implikasi Teoritis}

Pemaparan implikasi teoritis ini digunakan untuk memperkuat dukungan atas beberapa penelitian terdahulu yang dijadikan rujukan dan keterkaitannya dengan teori yang digunakan. Hasil dari penelitian sebagai berikut:

1. Hubungan stratejik dengan pemasok dapat mendorong praktik manajemen rantai pasok berjalan lebih baik. Hubungan stratejik dengan supplier memungkinkan organisasi untuk bekerja lebih efektif dengan sedikit supplier penting yang mana akan berbagi tanggung jawab terhadap kesuksesan suatu produk ( $\mathrm{Li}$ et al, 2006).

2. Pertukaran informasi merupakan faktor yang tidak dapat dipisahkan dalam proses rantai pasok. Partner dalam proses rantai pasok yang melakukan pertukaran informasi secara teratur akan dapat bekerja sama sebagai satu entitas. Secara bersama sama, mereka akan dapat mengerti 
kebutuhan dari pelanggan akhir dengan baik serta dapat merespon pasar dengan cepat (Li et al 2006).

3. Daya respon jaringan supplier (Supplier Network Responsiveness) adalah kemampuan supplier utama perusahaan dalam merespon permintaan customer (Prater et al, 2001). Semakin baik daya respon rantai pasok perusahaan akan memberikan dampak positif terhadap kinerja perusahaan.

4. Kemampuan pelayanan (Service Capability) adalah kemampuan perusahaan yang tercermin dalam penyediaan pelayanan yang unggul sehingga mampu mempertahankan pelanggan selama beberapa periode waktu. Kemampuan pelayanan sangat diperlukan dalam kaitan pembinaan hubungan dengan pelanggan.

5. Kemampuan manajeman relasi (Channel Management Capability) adalah kemampuan perusahaan dalam mengelola hubungan baik dengan pelanggan maupun pemasok, untuk menciptakan hubungan yang kolaboratif sehingga mampu menciptakan keunggulan kompetitif dan hubungan perdagangan dalam jangka waktu yang lama.

\section{Implikasi Kebijakan}

Dari hasil temuan penelitian, dapat disusun implikasi kebijakan yang disarankan untuk perusahaan, yaitu :

1. Praktik Manajemen Rantai Pasok

Perusahaan retailer pelumas diharapkan dapat membina hubungan yang baik dengan pemasok maupun pelanggan dan proses penerapan manajemen rantai pasok menggunakan teknologi terkini sehingga proses pertukaran informasi dapat berjalan dengan baik dan informasi yang diperoleh menjadi lebih akurat dalam menentukan arah kebijakan bisnis ke depan.

2. Daya Respon Rantai Pasok

Perusahaan retailer pelumas diharapkan dapat melakukan optimalisasi proses operasional dan logistic serta membangun kompetensi personil agar kegiatan proses rantai pasok dalam perusahaan dapat menjadi lebih responsif dan fleksibel terhadap pasar.

3. Kemampuan Perusahaan

Peusahaan retailer pelumas diharapkan dapat mengembangkan kemampuan internal perusahaan antara lain kemampuan dalam penekanan biaya operasional, kemampuan pelayanan kepada pelanggan, Kemampuan melihat kondisi pasar yang ada, kemampuan integrasi dan kemampuan manajemen relasi baik dengan pemasok maupun pelanggan.

4. Keunggulan Daya Saing

Perusahaan retailer pelumas diharapkan dapat menerapkan harga pelumas dan inovasi pelayanan yang bersaing, agar dapat menciptakan keunikan tertentu dan memberikan kontribusi dalam penciptaan keunggulan daya saing perusahaan.

\section{Kinerja Perusahaan}

Perusahaan retailer pelumas diharapkan dapat mengoptimalkan potensi sumber daya yang ada melalui ketepatan dalam menjalin hubungan antara pemasok dan pelanggan, optimalisasi biaya operasional, serta mengoptimalkan fungsi pemasaran dalam perusahaan agar memberikan peningkatan kinerja perusahaan yang lebih baik.

\section{Keterbatasan Penelitian}

Penelitian ini tidak terlepas dari beberapa keterbatasan yang ditemukan, antara lain:

1. Hipotesis kedua dan ketiga dalam penelitian ini belum terpenuhi/ditolak sehinggamasih perlu dilakukan penelitian lanjutan dengan skala 
sampel yang lebih luas terkait hubungan variabel tersebut khususnya dalam sektor industri retail pelumas.

2. Tidak semua responden dari target responden awal dapat diwawancarai dan mengembalikan kuesioner.

3. Luas area penelitian cukup besar yang membutuhkan waktu lama dalam penelitian

\section{Saran untuk Penelitian Mendatang}

Hasil-hasil penelitian ini dan keterbatasanketerbatasanyang ditemukan dalam penelitian dapat dijadikan sumber ide bagi pengembangan penelitian, maka perluasan penelitian yang disarankan dalam penelitian ini adalah dengan menambah variabel independen yang mempengaruhi keunggulan daya saing. Adapun variabel yang disarankan adalah strategi rantai pasok merujuk pada penelitian Wisner (2003) dan Green et al (2008).

\section{REFERENSI}

Arawati, A., \& Za'faran, H. (2008). The strategic supplier partnership in a supply chain management withquality and business performance. International Journal of Business and Management Science, 1(2), 129-145.

Al-Hawajreh, K. M., \& Attiany, M. S. (2014). The Effect of Supply Chain Responsiveness on Competitive Advantage: A Field Study of Manufacturing Companies in Jordan. European Journal of Business and Management, 6(13), 151-162.

Barney, J. (1991). Firm resources and sustained competitive advantage. Journal of Management, 17(1), 99-120.

Carvalho, H., Azevedo, S. G., \& Cruz-Machado, V. (2012). Agile and resilient approaches to supply chain management: Influence on performance and competitiveness. Logistics Research, 4(1-2), 49-62.

Day, G. S. (1994). The Capabilities of Market-Drive Organization. Journal of Marketing, 58(4), 37-52.

Finch, B. . (2006). Operations Now: Profitability, Processes, Performance (2nd ed.). United States: McGraw-Hill/ Irwin.

Green, K. W., \& Whitten, D. (2008). The impact of logistics performance on organizational performance in a supply chain context. Supply Chain Management: An International Journal, 13(4), 317-327.

Ha-brookshire, J. E., \& Dyer, B. (2009). The Impact of Firm Capabilities and Competitive Advantages on Import Intermediary Performance. Journal of Global Marketing, 22, 5-19.

Helfat, C. E., \& Peteraf, M. A. (2003). The Dynamic Resource-Based View : Capability Lifecycles. Strategic Management Journal, 24, 997-1010.

Holweg, M. (2005). The Three Dimensions of Responsiveness. International Journal of Operations \& Production Management, 25(7), 603-622.

Hsu, C.-C., Tan, K. C., Kannan, V. R., \& Keong Leong, G. (2009). Supply chain management practices as a mediator of the relationship between operations capability and firm performance. International Journal of Production Research, 47(3), 835-855. 
Li, S., Ragu-Nathan, B., Ragu-Nathan, T. S., \& Subba Rao, S. (2006). The impact of supply chain management practices on competitive advantage and organizational performance. Omega, 34(2), 107-124.

Lummus, R. R., Duclos, L. K., \& Vokurka, R. J. (2003). Supply Chain Flexibility: Building a New Model. Global Journal Of Flexible System Management, 4(4), 1-13.

Mentzer, J. T. (2001). Supply chain management. Thousand Oaks, CA: Sage Publications.

Mentzer, J. T., Min, S., \& Zacharia, Z. G. (2000). The nature of interfirm partnering in supply chain management. Journal of Retailing, 76(4), 549-568.

Metilda, R. M., \& Vivekanandan, K. (2011). Impact of Supply Chain Management practices on the competitive advantage of Indian retail supermarkets. International Journal of Logistics Systems and Management, 9(2), 170.

Mzoughi, N., Bahri, N., \& Ghachem, M. S. (2008). Impact of Supply Chain Management and ERP on Organizational Performance and Competitive Advantage: Case of Tunisian Companies. Journal of Global Information Technology Management, 11(3), 24-46.

Paulraj, A., Chen, I. J., \& Lado, A. A. (2012). An Empirical Taxonomy of Supply Chain Management Practices. Journal of Business Logistics, 33(3), 227-244.

Porter, M. E. (1985). Competitive Advantage; Creating and Sustaining Superior Performance. New York: The Free Press.

Prater, E., Biehl, M., \& Smith, M. A. (2001). International supply chain agility: Tradeoffs between flexibility and uncertainty. International Journal of Operations \& Production Management, 21(5/6), 823-839.

Rose, R. C., Abdullah, H., \& Uli, J. (2010). The Relationship Between Organisational Competitive Advantage and Performance. Asian Academy of Management Journal, 15(2), 157-173.

Singh, R., Sandhu, H. S., Metri, B. A., \& Kaur, R. (2010). Relating Organised Retail Supply Chain Management Practices, Competitive Advantage and Organisational Performance. The Journal of Business Perspective, 14(3), 173 - 190.

Sukati, I., Abdul Hamid, A. B., Baharun, R., Tat, H. H., \& Said, F. (2011). A study of supply chain management practices: An empirical investigation on consumer goods industry in Malaysia. International Journal of Business and Social Science, 2(17), 166-176.

Sukati, I., \& Hamid, A. (2012). Competitive advantage through supply chain responsiveness and supply chain integration. International Journal of Business and Commerce, 1(7), 1-11.

Tan, K. C., \& Kannan, V. R. (1998). Supply Chain Management: Supplier Performance and Firm Performance. International Journal of Purchasing \& Materials Management, 34(3), 2-9.

Tan, K. C., Lyman, S. B., \& Wisner, J. D. (2002). Supply Chain Management: a Strategic Perspective. International Journal of Operations \& Production Management, 22(6), 614631.

Teece, D. J., Pisano, G., \& Shuen, A. (1997). Dynamic Capabilities and Strategic Management. Strategic Management Journal, 18(7), 509-533.

Thatte, A. A. (2013). Impact of SCM Practices of A Firm On Supply Chain Responsiveness And Competitive Advantage Of A Firm. The Journal of Applied Business Research, 29(2), 499530.

Tuan, N. P., \& Yoshi, T. (2010). Organisational Capabilities, Competitive Advantage And Performance In Supporting Industries In Vietnam. Asian Academy of Management Journal, 15(1), 1-21. 
Ueki, Y. (2013). Supply Chain Collaboration and Responsiveness. Institute of Developing Economies, JETRO, (416).

Ulrich, D., \& Lake, D. (1991). Organizational capability: creating competitive advantage. Academy of Management Executive, 5(1), 77-92.

Vorhies, D. W., \& Morgan, N. A. (2005). Benchmarking Marketing Capabilities for Sustainable Competitive Advantage. Journal of Marketing, 69, 80-94.

Wisner, J. D. (2003). A Structural Equation Model of Supply Chain Management Strategies and Firm Performance. Journal of Business Logistics, 24(1), 1-26.

Yeoh, P.-L., \& Roth, K. (1999). An Empirical Analysis Of Sustained Advantage In The U.S. Pharmaceutical Industry: Impact Of Firm Resources And Capabilities. Strategic Management Journal, 20(7), 637-653. 